\title{
SYNTHESIS, CHARACTERIZATION AND ANTIMICROBIAL ACTIVITY OF NEW Cu (II), Co (II) AND Sn (II) COMPLEXES WITH THE SODIUM HYDROTRIS(2-MERCAPTOTHIAZOLYL)BORATE LIGAND
}

\author{
Lorena S. Ferreira ${ }^{a}$, Jéssica T. Andradea, William G. Limaa, Juliano de P. Souza ${ }^{a}$, Rafael C. R. Chagas ${ }^{a}$, Camyla A. Leonela, \\ Laís C. Cunha ${ }^{a}$, Karina M. S. Herrera ${ }^{a}$, Alysson V. Braga ${ }^{a}$, Luís F. Soares ${ }^{a}$ and Jaqueline M. S. Ferreira ${ }^{a, *}, \mathbb{C}$ \\ ${ }^{a}$ Campus Centro Oeste Dona Lindu, Universidade Federal de São João Del-Rei, 35501-296 Divinópolis - MG, Brasil
}

Recebido em 27/11/2019; aceito em 05/02/2020; publicado na web em 16/04/2020

\begin{abstract}
The emergence of antibiotic resistance among microbial pathogens is a serious public health problem, resulting in a constant need of discovering new antibiotics. For this purpose, we synthetized and determined the antimicrobial activity of copper $(\mathrm{Cu}), \mathrm{cobalt}(\mathrm{Co})$, and tin (Sn) complexes coordinated with scorpionate ligand in a tridentate mode against microorganisms of clinical importance. New complexes with the sodium hydrotris(2-mercaptothiazolyl)borate ligand were characterized by physicochemical and spectroscopic techniques (UV-vis, IR, ${ }^{1} \mathrm{H}$ and ${ }^{13} \mathrm{C}$ NMR). Moreover, their antimicrobial activity was evaluated using microdilution broth method. Cytotoxicity was determined in Vero cells and the selectivity index (SI) was calculated. The coordination with metals increased the ligand antimicrobial activity, which showed no activity when evaluated alone (MIC>1,080 $\mu \mathrm{M})$. Cu-complex (1) had activity against Candida albicans and C. krusei, with MICs of 130 and $66 \mu \mathrm{M}$, respectively. The compounds had low toxicity on Vero cells and chemo-informatics assays corroborated a low systemic toxic effect. The SI revealed that the compound $\mathbf{1}$ was 16 times more selective for $C$. krusei and 8 times more selective for $C$. albicans in relation to Vero cells. The $\mathrm{Cu}$-complex stands out as a potential prototype for the development of new antifungal agents.
\end{abstract}

Keywords: Antifungal activity; Antibacterial activity; Chemo-informatics assays; Thiazoline; Metal complexes.

\section{INTRODUCTION}

Antimicrobial drug resistance is a growing global public health problem $^{1}$ and many cases of resistant strains of bacteria and yeasts in hospital environments are reported every year. ${ }^{2}$ In USA, multidrug resistant (MDR) microorganisms cause 2 million infections with 23,000 deaths annually and, in Europe, MDR pathogens are associated with about 25,000 deaths per year. However, the situation in Asia and other developing countries is even more critical. ${ }^{3,4}$ Currently, healthcare-associated infections (HAI) are one of the major therapeutic challenges. HAI are those acquired inside the hospital and in several categories of patients with major contact with the healthcare system, ${ }^{5}$ becoming a major health threat worldwide, causing both morbidity and mortality as well as prolonging hospital stay time. ${ }^{6,7}$

In view of this problematic situation, coordination chemistry has become increasingly important for the development of new antimicrobial compounds ${ }^{8,9}$ and coordination compounds have shown promising antifungal and antibacterial activity against different species. ${ }^{10,11}$ In addition, metal complexes can also be used as a solution for the problem of multidrug resistant (MDR) bacteria. ${ }^{11}$

Ligands have great influence on the synthesis and biological activity of coordination compounds. ${ }^{12}$ In this context, thiazolines are a class of ligands formed by heterocyclic five-membered rings that contain nitrogen and sulfur atoms, which have a plurality of coordination modes. ${ }^{13}$ Thiazolines are known for various biological activities such as anti-inflammatory, ${ }^{14}$ anticancer ${ }^{15}$ and antimicrobial, ${ }^{16}$ which make the thiazoline-derived compounds important in medicinal chemistry studies. Therefore, compounds derived from 2-thiazolidine-2-thiol have been synthesized and used in metal complexes formation ${ }^{16-18}$ such as the 2-thiazoline-2-thiol-derivative ligand ${ }^{19}$ that is included in a class of ligands called scorpionates. ${ }^{20}$ The scorpionate chemistry is an active area of research, especially with

*e-mail: jackmaria4@gmail.com ligands based on borate chelators. ${ }^{21}$ Several metal complexes with this class of ligands have already been synthesized and characterized..$^{22,23}$ The ligand hydrotris(2-mercaptothiazolyl)borate $(\mathrm{L})$ is an S-donor scorpionate and its metal complexes have not been commonly used in research. ${ }^{24}$

Therefore, we synthesized and evaluated the antimicrobial potential new metal complexes of copper $[\mathrm{Cu}(\mathrm{L}) \mathrm{Cl}](\mathbf{1})$, cobalt $[\mathrm{Co}(\mathrm{L}) \mathrm{Cl}](\mathbf{2})$, and tin $\left[\mathrm{Sn}\left(\mathrm{L}_{)} \mathrm{Cl}_{2}\right](\mathbf{3})\right.$. These complexes were characterized by physicochemical methods and antimicrobial susceptibility was tested against yeasts, and both Gram-positive and Gram-negative bacteria strains of medical importance.

\section{EXPERIMENTAL}

Synthesis of sodium hydrotris(2-mercaptothiazolyl)borate (L) ligand and metal complexes

All reagents and solvents were purchased from commercial sources and used without further purification. Compounds were synthetized and characterized by physicochemical and spectroscopic techniques. The melting point (M.P) determinations were performed in the LSIII basic apparatus (LogenScientific). Molar conductivities of $10^{-3} \mathrm{~mol} \mathrm{~L}^{-1}$ solutions of the solid complexes in dimethylformamide and dimethylsulfoxide (DMSO) were measured at room temperature $\left(25 \pm 2{ }^{\circ} \mathrm{C}\right)$ using an 856 and Touch Control 840 control screen (Metrohm, Switzerland) conductivity module. UV-vis spectral data were obtained in the $200-800 \mathrm{~nm}$ range on a UV-Genesys 10S spectrophotometer (Thermo Fisher Scientific, USA). Infrared spectra (FT-IR) were recorded in the range of 400-4000 $\mathrm{cm}^{-1}$ on an Affinity 1 spectrometer (Shimadzu, Japan) with pressed $\mathrm{KBr}$ pellets. Elemental analyses were performed on an elementary analyzer CHNS/O 2400 (PerkinElmer, USA). ${ }^{1} \mathrm{H}$ and ${ }^{13} \mathrm{C}$ nuclear magnetic resonance (NMR) spectra were obtained at $200 \mathrm{MHz}$ and $50 \mathrm{MHz}$ on a spectrometer Bruker ARX-200 using DMSO- $d_{6}$ as solvent. 
The sodium hydrotris(2-mercaptothiazolyl)borate ((L)- $\left.\left(\mathrm{Na}\left[\mathrm{C}_{9} \mathrm{H}_{13} \mathrm{~N}_{3} \mathrm{~S}_{6} \mathrm{~B}\right]\right)\right)$ ligand was prepared according to Soares et al. ${ }^{19}$ using $\mathrm{NaBH}_{4}$ instead of $\mathrm{KBH}_{4}$. All complexes were prepared following the general method. A sample of $0.5 \mathrm{mmol}$ anhydrous $\mathrm{MCl}_{2}(\mathrm{M}: \mathrm{Cu}, \mathrm{Co}$, or $\mathrm{Sn})$ dissolved in methanol $(10 \mathrm{~mL})$ was added to a methanolic solution $(10 \mathrm{~mL})$ containing $\mathrm{L}(0.5 \mathrm{mmol})$. For the complex $[\mathrm{Cu}(\mathrm{L}) \mathrm{Cl}] . \mathrm{H}_{2} \mathrm{O}(\mathbf{1})$, the reaction was heated under reflux for $3 \mathrm{~h}$ and the solid complex was separated by simple filtration, washed three times with methanol and dried at room temperature. For the $[\mathrm{Co}(\mathrm{L}) \mathrm{Cl}] \cdot \mathrm{H}_{2} \mathrm{O}(2)$ and $\left[\mathrm{Sn}(\mathrm{NaL}) \mathrm{Cl}_{2}\right] \cdot 3 \mathrm{H}_{2} \mathrm{O}(3)$ complexes, the resulting solution remained stirring for $3 \mathrm{~h}$ and precipitates were separated by filtration, washed three times with methanol and dried at room temperature. The optimized structures proposed for the complexes are shown in Figure 1.

\section{Microorganisms}

The microorganisms used in the study originate from the American Type Culture Collection (ATCC) and were kindly provided by the Reference Microorganisms Laboratory of the Oswaldo Cruz Foundation (FIOCRUZ), Rio de Janeiro, Brazil. Antibacterial assays were carried out using five Gram-negative (Escherichia coli ATCC 25922, Acinetobacter baumannii ATCC 19606, Enterobacter cloacae ATCC 23355, Pseudomonas aeruginosa ATCC 25619 and Proteus mirabilis ATCC 15290) and three Gram-positive (Staphylococcus aureus ATCC 29213, Staphylococcus saprophyticus ATCC 15305, Streptococcus agalactiae ATCC 13813) bacteria. In the antifungal assay, three yeasts were employed, namely Candida genus (C. albicans ATCC 14053, C. krusei ATCC 34135 and C. glabrata ATCC 2001).

\section{Antimicrobial susceptibility tests}

The antimicrobial activity of the ligand and the three complexes were determined using minimum inhibitory concentration (MIC) by the broth microdilution method as previously described by the Clinical and Laboratory Standard Institute (CLSI). The M27-A325 reference protocol was employed to determine antifungal activity and the M07-A9 ${ }^{26}$ document was followed to evaluate the antibacterial activity of the compounds, both with minor modifications..$^{27,28} \mathrm{MIC}$ assays were carried out in sterilized 96-well microtiter plates using Mueller Hinton broth (Himedia, India) and Sabouraud-dextrose broth (Himedia, India) for antibacterial and antifungal tests, respectively. The compounds were diluted in dimethyl sulfoxide 10\% (DMSO; Synth, Brazil) to create stock solutions, which was serially diluted in concentrations ranging from 4 to $1,080 \mu \mathrm{mol} \mathrm{L}^{-1}$ to perform the antimicrobial tests. A volume of $100 \mu \mathrm{L}$ containing diluted Candida and bacterial cells suspension were added to each well. Ketoconazole (Pharmanostra, Brazil) and Streptomycin (Sigma-Aldrich, Brazil) were included as a positive control in the antifungal and antibacterial assays, respectively, and DMSO was used at $\leq 2 \% \mathrm{v} / \mathrm{v}$ as solvent control. The plates were incubated at $35 \pm 2{ }^{\circ} \mathrm{C}$ for $48 \mathrm{~h}$ for yeasts and $18 \mathrm{~h}$ for bacteria. After incubation, the MIC of each compound was defined as the lowest concentration required to inhibit visible fungal and bacterial growth.

The minimal fungicidal concentration (MFC) and minimal bactericidal concentration (MBC) were determined by subculturing $0.01 \mathrm{~mL}$ from each well corresponding to the MIC in Sabourauddextrose agar (Kasvi, Germany) and Nutrient agar (Himedia, India) plates for yeast and bacteria, respectively. ${ }^{28}$ MFC and MBC were defined as the lowest concentration that prevent fungal and bacterial growth. All tests were performed in triplicate.

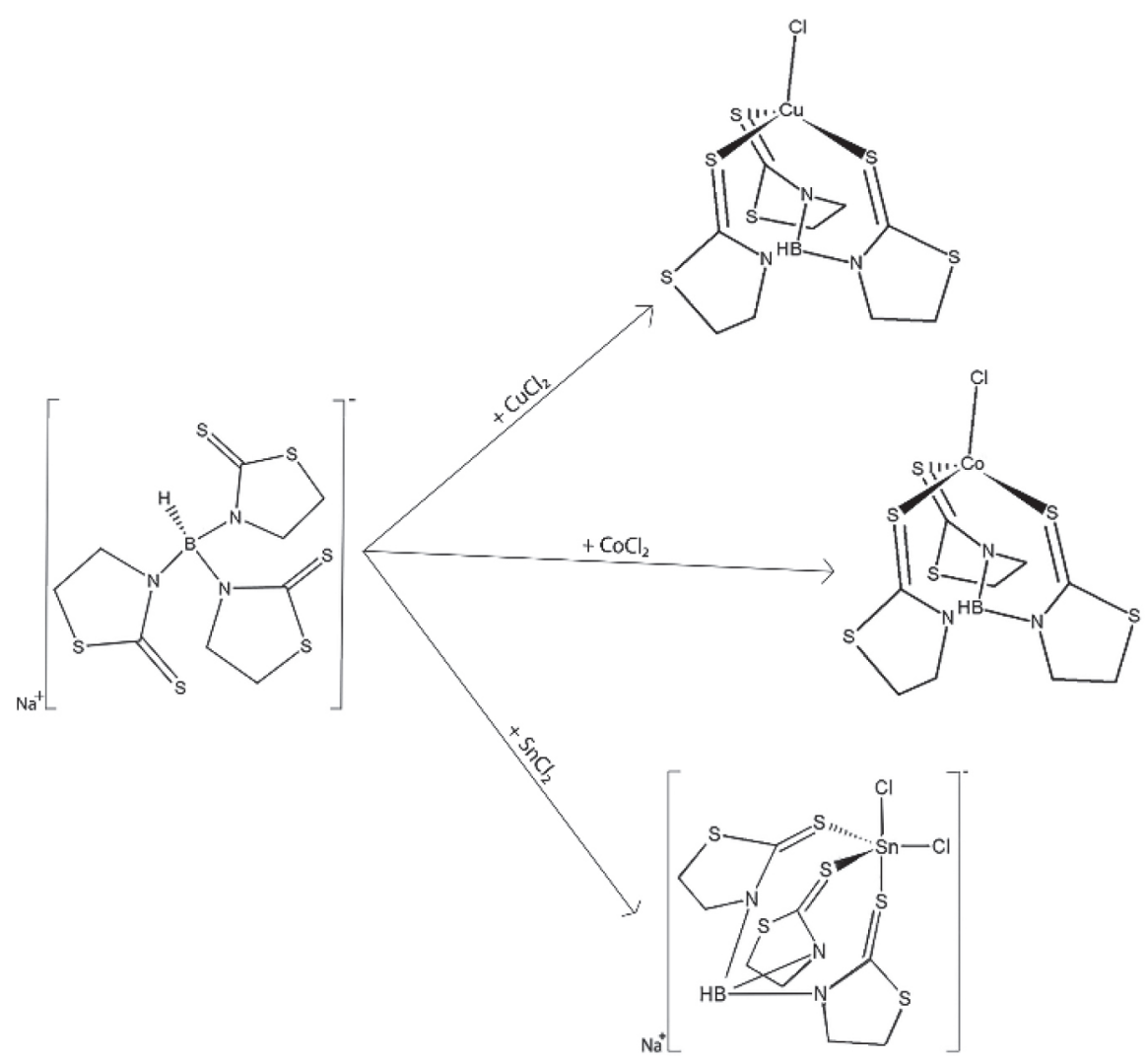

Figure 1. Chemical structure of sodium hydrotris(2-mercaptothiazolyl)borate ligand $(L)$ and the scheme of the metal complexes synthetic pathways, resulting in the proposed structure of $[\mathrm{Cu}(\mathrm{L}) \mathrm{Cl}],[\mathrm{Co}(\mathrm{L}) \mathrm{Cl}]$, and $\mathrm{Na}\left[\mathrm{Sn}(\mathrm{L}) \mathrm{Cl}_{2}\right]$ complexes 


\section{Cytotoxicity assay}

Cytotoxicity of the compounds against mammalian cells was determined by the colorimetric 3-(4.5-dimethylthiazol-2-yl)-2.5diphenyltetrazolium bromide (MTT) (Sigma-Aldrich, Brazil) assay. ${ }^{29}$ For this purpose, Vero cell line derived from the African green monkey (Cercopithecus aethiops) kidney epithelium (ATCC CCL-81; Maryland, USA) were cultured in Dulbecco's Modified Eagle medium (DMEM; Cultilab, Brazil) supplemented with $10 \%$ fetal bovine serum (Gibco, India) and $0.3 \%$ of solution content penicillin $\left(10,000 \mathrm{U} \mathrm{mL}^{-1}\right)$, streptomycin $\left(10 \mathrm{mg} \mathrm{mL}^{-1}\right)$ and amphotericin $\mathrm{B}$ $\left(2 \mu \mathrm{g} \mathrm{mL}^{-1}\right)$ (Sigma-Aldrich, Brazil). Cell cultures were maintained at $35 \pm 2{ }^{\circ} \mathrm{C}$ in a humidified atmosphere of $5 \% \mathrm{CO}_{2}$ and their viability was assessed after exposure for $48 \mathrm{~h}$ to the compounds. The cytotoxic concentrations for $50 \%$ of the cells $\left(\mathrm{CC}_{50}\right)$ in culture were calculated by linear regression analysis,,$^{27,29}$ and the tests were performed in three independent experiments. The relation between cytotoxicity and antimicrobial activity was determined through the selectivity index (SI). ${ }^{30}$ Selective Index values were determined by the ratio of $\mathrm{CC}_{50}$ to MIC, indicating the specificity of complexes towards pathogens and mammalian cells.

\section{Chemo-informatic analysis}

To calculate the physicochemical (LogP, LogS, Molecular Weight, Numbers of acceptor and donors groups of hydrogen bond), toxicological (irritative, tumorigenic and anti-reproductive effects) and pharmaceutical (Druglikeness) properties of compounds, chemo-informatics analyses were employed. The two-dimensional chemical structures of the ligand and complexes 1-3 were inserted into DataWarrior 4.2.2 software ${ }^{31}$ on a Windows platform in a Dell Vostro 2520 computer, and the parameters of interest were calculated. After, values of molecular weight, $\log \mathrm{P}$, and number of donor and acceptor groups of hydrogen bonds were compared with the Lipinski's rules. ${ }^{32}$

\section{RESULTS AND DISCUSSION}

The $\mathrm{Cu}$ (II), Co (II), and Sn (II) complexes were prepared in a 1:1 molar ratio resulting in yields of 56-72\% and were obtained as different colored powders (yellow, green, and yellow, respectively) that are stable in air. All the compounds and their intermediates were successfully characterized by FT-IR, UV-vis, ${ }^{1} \mathrm{H}$ and ${ }^{13} \mathrm{C}$ NMR. Spectral details are shown in supplementary material.

The synthesis of the compounds was performed as described in the literature ${ }^{19}$ and their structures have been elicited based on characterization since X-ray crystallography was not possible due to failure of obtaining crystals for useful analysis. The results of elemental analyses $(\mathrm{C}, \mathrm{H}$, and $\mathrm{N}$ ) are in agreement with those calculated for the suggested formula and the decomposition temperature of all metal complexes indicate the purity and the formation of a new compound. ${ }^{33}$ The 1:1 stoichiometry (L:M) is in agreement with the proposed structure through the proportion of carbon, hydrogen and nitrogen found in the complexes by the elemental analyses.

The characterization data for the ligand and complexes are also summarized in Table 1. The molar conductivities of metal complexes show that compounds $\mathbf{1}$ and $\mathbf{2}$ have no electrolytic nature while compound $\mathbf{3}$, indicates that it is 1:1 electrolytes. By the infrared spectral data, the coordination was confirmed by comparing the infrared spectrum of the ligand and its derivative complexes. The ligand spectrum exhibited bands at $1481(\mathrm{~B}-\mathrm{N})$ and 1089, $1010(\mathrm{C}=\mathrm{S})$.

In the electronic spectra, one band at $284 \mathrm{~nm}$ ( $\varepsilon=126201 \mathrm{~L} \mathrm{~mol}^{-1} \mathrm{~cm}^{-1}$ ) was observed for the ligand $(\mathrm{L})$ in the ultraviolet region. The ${ }^{1} \mathrm{H}$ NMR spectrum of the free ligand showed two triplets at $\delta 4.17(J=7.4 \mathrm{~Hz})$ and $\delta 3.18 \mathrm{ppm}(J=7.4 \mathrm{~Hz})$ attributed to hydrogens bonded in secondary carbon atoms of the thiazole ring ( $\mathrm{C} 1$ and $\mathrm{C} 2)$. In the ${ }^{13} \mathrm{C} N M R$ spectra, three signals were observed at $\delta 195.2(\mathrm{C}=\mathrm{S}), \delta 59.74(\mathrm{C} 1-\mathrm{N})$ and $\delta 30.56 \mathrm{ppm}(\mathrm{C} 2-\mathrm{S})$.

Compared to the ligand bands, ${ }^{34-36}$ variations in the wave number in $\mathrm{C}=\mathrm{S}$ band were observed for all complexes, indicating a weakening of the bond involved in coordination and the presence of metal coordinated to the sulfur atom of the $\mathrm{C}=\mathrm{S}$ (Table 1). Instead, the band corresponding to $v \mathrm{~B}-\mathrm{N}$ in complexes $\mathbf{2}$ and $\mathbf{3}$ was shifted to higher frequencies opposite the free ligand, indicating that the coordination affects the B-N bond (Table 1). This behavior is similar to that observed for coordination of the organic compound thiourea via the $\mathrm{S}$ atom, where there is a decrease in the frequency of $\mathrm{vC}=\mathrm{S}$ and an increase in frequency of $\mathrm{vC}-\mathrm{N} .^{37}$

For the copper compound in the ultraviolet region, a band at $272 \mathrm{~nm}\left(\varepsilon=7650 \mathrm{~L} \mathrm{~mol}^{-1} \mathrm{~cm}^{-1}\right)$ was observed and attributed to the $\mathrm{n}-\pi *$ transition, confirming the coordination via the sulfur atom of the $\mathrm{C}=\mathrm{S}$ bond inferred by the IV since this band was present in the ligand at $284 \mathrm{~nm}\left(\varepsilon=8370 \mathrm{~L} \mathrm{~mol}^{-1} \mathrm{~cm}^{-1}\right)$. Any other band can be seen in the 500-800 $\mathrm{nm}$ region, which indicates that copper is in a distorted tetrahedral environment. ${ }^{38,39}$

In the spectrum of cobalt complex, the same behavior of the copper complex with a hypsochromic shift to $268 \mathrm{~nm}\left(\varepsilon=9830 \mathrm{~L} \mathrm{~mol}^{-1} \mathrm{~cm}^{-1}\right)$ for the $\mathrm{n}-\pi^{*}$ transition was evidenced, also indicating coordination. ${ }^{40}$ Moreover, two bands at $584 \mathrm{~nm}\left(\varepsilon=895 \mathrm{~L} \mathrm{~mol}^{-1} \mathrm{~cm}^{-1}\right)$ and $650 \mathrm{~nm}$ ( $\varepsilon=1363 \mathrm{~L} \mathrm{~mol}^{-1} \mathrm{~cm}^{-1}$ ) attributed to $d-d$ transitions of Co (II) in a tetrahedral field were evidenced. ${ }^{40}$ For the tin complex, as expected for a $d^{10}$ ion, only the bands attributed to the $\pi-\pi^{*}$ and $n-\pi^{*}$ were evidenced in $276 \mathrm{~nm}\left(\varepsilon=7990 \mathrm{~L} \mathrm{~mol}^{-1} \mathrm{~cm}^{-1}\right)$.

Compared to the ligand, complex $\mathbf{3}$ had a variation in chemical shift in the ${ }^{1} \mathrm{H}$ NMR spectral result to $\delta 3.87$ and $\delta 3.50 \mathrm{ppm}$, which confirms the coordination. The ${ }^{13} \mathrm{C}$ NMR data also show differences in chemical shifts of the ligand signals compared to complex $\mathbf{3}$, with three triplets observed at $\delta 199.45(\mathrm{C}=\mathrm{S}), \delta 51.91(\mathrm{C} 1-\mathrm{N})$ and

Table 1. Physical-chemical characteristics and spectroscopic data of ligand and metal complexes (1-3)

\begin{tabular}{|c|c|c|c|c|c|c|c|c|c|}
\hline \multirow{2}{*}{ Compounds } & \multirow{2}{*}{ Yield (\%) } & \multirow{2}{*}{ M.P $\left({ }^{\circ} \mathrm{C}\right)$} & \multirow{2}{*}{$\Lambda * *$} & \multicolumn{3}{|c|}{ Found (calculated) $\%$} & \multicolumn{3}{|c|}{$\operatorname{IR}\left(\mathrm{cm}^{-1}\right)$} \\
\hline & & & & $\mathrm{C}$ & $\mathrm{H}$ & $\mathrm{N}$ & $v(\mathrm{C}=\mathrm{S})$ & $v(\mathrm{~B}-\mathrm{N})$ & $v\left(\mathrm{H}_{2} \mathrm{O}\right)$ \\
\hline $\mathrm{Na}\left[\mathrm{C}_{9} \mathrm{H}_{13} \mathrm{~N}_{3} \mathrm{~S}_{6} \mathrm{~B}\right](\mathrm{NaL})$ & 87 & 140 & - & - & - & & $1089-1010$ & 1481 & - \\
\hline$[\mathrm{Cu}(\mathrm{L}) \mathrm{Cl}] \cdot \mathrm{H}_{2} \mathrm{O}(\mathbf{1})$ & 56 & $152 d$ & $8.28 * * *$ & $\begin{array}{c}22.66 \\
(22.36)\end{array}$ & $\begin{array}{c}3.12 \\
(3.10)\end{array}$ & $\begin{array}{c}8.98 \\
(8.69)\end{array}$ & $1045-981$ & - & 3557 \\
\hline$[\mathrm{Co}(\mathrm{L}) \mathrm{Cl}] \cdot \mathrm{H}_{2} \mathrm{O}(\mathbf{2})$ & 72 & $160 d$ & 12.06 & $\begin{array}{c}22.65 \\
(22.58)\end{array}$ & $\begin{array}{c}3.16 \\
(3.13)\end{array}$ & $\begin{array}{c}8.32 \\
(8.78)\end{array}$ & $1051-997$ & 1496 & 3435 \\
\hline $\mathrm{Na}\left[\mathrm{Sn}(\mathrm{L}) \mathrm{Cl}_{2}\right] \cdot 3\left(\mathrm{H}_{2} \mathrm{O}\right)(\mathbf{3})$ & 60 & $70 d$ & 69.2 & $\begin{array}{c}16.99 \\
(17.07)\end{array}$ & $\begin{array}{c}3.13 \\
(3.03)\end{array}$ & $\begin{array}{c}6.44 \\
(6.64)\end{array}$ & $1045-1001$ & 1521 & 3134 \\
\hline
\end{tabular}

$* *\left(\Omega^{-1} \mathrm{~cm}^{2} \mathrm{~mol}^{-1}\right) . * * *$ DMSO. M.P: melting point; IR: infrared; $\Lambda$ : conductivity. 
$\delta 33.37$ ppm (C2-S). However, complexes $\mathbf{1}$ and $\mathbf{2}$ are paramagnetic and do not provide useful information due to the extension signals in the spectrum.

Antimicrobial assay showed that complex 1 had the best antifungal activity with MIC values ranging from 66 to $530 \mu \mathrm{mol} \mathrm{L}^{-1}$ (Table 2). Additionally, complex 1 presented fungicidal activity against C. albicans and C. glabrata (MFC of $260 \mu \mathrm{mol} \mathrm{L}^{-1}$ ). It is noteworthy that the strain of $C$. glabrata used in this study is highly resistant to azoles drugs, such as ketoconazole, fluconazole, and itraconazole. ${ }^{41}$ On the other hand, complex 1 exhibited unsatisfactory antibacterial activity in relation to streptomycin, as it was only moderately active against $S$. aureus, $S$. saprophyticus and $P$. aeruginosa (MICs in the ranges from 260 to $530 \mu \mathrm{mol} \mathrm{L}{ }^{-1}$ ). Complexes $\mathbf{2}$ and $\mathbf{3}$ demonstrated activity against the three yeasts, all of them with MIC values equal to $530 \mu \mathrm{mol} \mathrm{L}^{-1}$ (Table 2). In addition, the ligand did not show activity when evaluated alone $\left(\mathrm{MIC}>1080 \mu \mathrm{mol} \mathrm{L}{ }^{-1}\right)$.

The copper complex (1) showed the best antifungal activity being four times more active than the ketoconazole against $C$. albicans, the most clinically relevant fungal pathogen..$^{42}$ In fact, some studies have shown that copper-coordinate compounds have a higher antifungal activity than substances complexed with another transition metal such as $\mathrm{Ni}, \mathrm{Zn}, \mathrm{Co}$ or $\mathrm{Cr}^{30,31,43}$ The antifungal effect of $\mathrm{Cu}$ (II) complex with porphyrin core dendrimeric ligand was two times higher compared to the Co (II) and Ni (II) complexes. ${ }^{44}$ In addition, a previous study found that the coordination of $\mathrm{Cu}$ (II) with amphotericin $\mathrm{B}$ increased its antifungal activity and reduced the toxicity of this drug against human dermal fibroblasts, indicating that the presence of this transition metal improves the therapeutic index of antifungal substances in vitro. ${ }^{45}$ Furthermore, the metal complexes with $\mathrm{Cu}$ (II) (compound 1) presented a low activity against bacteria, which was also evidenced by Vaidya and collaborators. ${ }^{46}$ The authors tested the antibacterial activity of some metal ion solutions (silver, copper, platinum, gold and palladium) and showed that cooper has higher

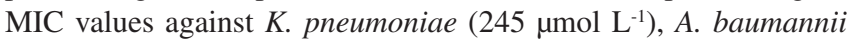
$\left(245 \mu \mathrm{mol} \mathrm{L}^{-1}\right)$ and E. faecium $\left(980 \mu \mathrm{mol} \mathrm{L}^{-1}\right)$ than all ions studied. ${ }^{46}$

The cytotoxicity assay showed that the compounds have $\mathrm{CC}_{50}$ values ranging from 1000 to $1505 \mu \mathrm{mol} \mathrm{L} \mathrm{L}^{-1}$ (Table 3) while Ketoconazole was considerably cytotoxic $\left(\mathrm{CC}_{50}\right.$ of $\left.79.93 \mu \mathrm{mol} \mathrm{L}-1\right)$ whereas streptomycin was not cytotoxic $\left(\mathrm{CC}_{50}\right.$ of $\left.262 \mu \mathrm{mol} \mathrm{L} \mathrm{L}^{-1}\right)$. The $\mathrm{CC}_{50}$ indicated that the compounds $\mathbf{1 - 3}$ had low toxicity to Vero cells, which is an important predictor of safety since the majority of clinically available antimicrobials are excreted primarily via the urinary tract, where they tend to accumulate. ${ }^{47}$ In contrast to our findings, another study ${ }^{48}$ showed that copper (II) complexes with fluoroquinolonas exhibit high cytotoxicity against Vero cell $\left(\mathrm{CC}_{50}\right.$ ranging from 2.19 to $2.45 \mu \mathrm{g} \mathrm{mL}^{-1}$ ). Such effect was attributed to the transition metal.

As the cytotoxic values of complexes 1-3 were higher than the effective antimicrobial concentrations, the SI values were broad (Table 3). These complexes showed SI of 0.9 to 4 against bacteria,

Table 2. Antimicrobial activity of complexes 1-3 against bacteria and fungi of medical importance

\begin{tabular}{|c|c|c|c|c|c|c|c|c|c|c|}
\hline & \multicolumn{2}{|r|}{1} & \multicolumn{2}{|r|}{2} & \multicolumn{2}{|r|}{3} & \multicolumn{2}{|c|}{ Streptomycin } & \multicolumn{2}{|c|}{ Ketoconazole } \\
\hline & $\mathrm{MIC}^{*}$ & MFC/MBC** & MIC & $\mathrm{MFC} / \mathrm{MBC}$ & MIC & $\mathrm{MFC} / \mathrm{MBC}$ & MIC & MBC & MIC & MFC \\
\hline \multicolumn{11}{|l|}{ Gram-Negative bacteria } \\
\hline E. coli ATCC 25922 & NA & - & NA & - & NA & - & 6.7 & - & - & - \\
\hline A. baumannii ATCC 19606 & NA & - & NA & - & NA & - & 430 & - & - & - \\
\hline E. cloacae ATCC 23355 & NA & - & NA & - & NA & - & 6.7 & - & - & - \\
\hline P. aeruginosa ATCC 25619 & 530 & NA & $\mathrm{NA}$ & - & NA & - & 6.7 & - & - & - \\
\hline P. mirabilis ATCC 15290 & NA & - & NA & - & NA & - & 26.8 & - & - & - \\
\hline \multicolumn{11}{|l|}{ Gram-Positive bacteria } \\
\hline S. aureus ATCC 29213 & 530 & NA & NA & - & NA & - & 13.4 & - & - & - \\
\hline S. saprophyticus ATCC 15305 & 260 & NA & NA & - & NA & - & 6.7 & - & - & - \\
\hline S. agalactiae ATCC 13813 & NA & - & NA & - & NA & - & 6.7 & - & - & - \\
\hline \multicolumn{11}{|l|}{ Yeasts } \\
\hline C. albicans ATCC 14053 & 130 & 260 & 530 & $>1,080$ & 490 & $>990$ & - & - & 470 & 470 \\
\hline C. krusei ATCC 34135 & 66 & $>1080$ & 530 & $>1,080$ & 490 & $>990$ & - & - & 7.3 & 14.7 \\
\hline C. glabrata ATCC 2001 & 260 & 260 & 530 & $>1,080$ & 490 & $>990$ & - & - & 235 & NA \\
\hline
\end{tabular}

NA: Inactive; -: Not evaluated. *Values given in $\mu$ M. MFC: Minimal Fungicidal Concentration. MBC: Minimal Bactericidal Concentration.

Table 3. Cytotoxicity in Vero cells $\left(\mathrm{CC}_{50}\right)$ and selectivity index (SI) values for complex 1-3

\begin{tabular}{lccccccc}
\hline \multirow{2}{*}{ Compounds } & $\mathrm{CC}_{50}{ }^{*}$ & \multicolumn{5}{c}{ SI } \\
\cline { 3 - 8 } & & P. aeruginosa & S. aureus & S. saprophyticus & C. albicans & C. krusei & C. glabrata \\
\hline $\mathbf{1}$ & 1000 & 2 & 2 & 4 & 7.98 & 16 & 4 \\
$\mathbf{2}$ & 1505 & - & - & - & 2.81 & 2.81 & 2.81 \\
$\mathbf{3}$ & 1482 & - & - & - & 2.81 & 2.81 & 2.81 \\
Ketoconazole & 79.93 & - & - & - & 0.16 & -10.89 & - \\
Streptomycin & 262 & 9.7 & 39 & - & - & - & - \\
\hline
\end{tabular}

*Values expressed in $\mu \mathrm{mol} \mathrm{L}{ }^{-1}$. (-) Not evaluated. Ketoconazole: Antifungal control. Streptomycin: antibacterial control. CC $\mathrm{C}_{50}$ : Cytotoxic concentrations for $50 \%$ of the cells. 
Table 4. Chemicals and toxicological properties of sodium hydrotris(2-mercaptothiazolyl)borate ligand and its metallic complexes

\begin{tabular}{|c|c|c|c|c|c|c|c|c|c|c|}
\hline & Symbol & $\begin{array}{c}\text { Total Mol } \\
\text { weight } \\
\left(\mathrm{g} \mathrm{mol}^{-1}\right)\end{array}$ & cLogP & H-Acceptors & H-Donors & Irritant & Mutagenic & $\begin{array}{l}\text { Reproductive } \\
\text { effective }\end{array}$ & Druglikeness & $\begin{array}{l}\text { Lipinski's } \\
\text { rule }\end{array}$ \\
\hline Ligand & $\mathrm{L}$ & 365.422 & -0.99 & 3 & 0 & None & none & None & -2.8611 & Respect all \\
\hline $\mathrm{Cu}(\mathrm{II})$ & 1 & 517.832 & -1.40 & 3 & 0 & None & none & None & -3.9953 & $\mathrm{MW}>500^{\mathrm{a}}$ \\
\hline Co (II) & 2 & 522.445 & -1.40 & 3 & 0 & None & none & None & -4.5653 & $\mathrm{MW}>500^{\mathrm{a}}$ \\
\hline
\end{tabular}

The physicochemical proprieties were calculated using DataWarrior software version 4.2.2.23 Lipinski's rule follows the criteria: Molecular weight (MW) is less than 500; $\log \mathrm{P}$ (the logarithm of the partition coefficient between water and 1-octanol) is less than 5; Number of groups in the molecule that can donate hydrogen atoms to hydrogen is less than 5; Number of groups that can accept hydrogen atoms to form hydrogen bonds is less than $10 .{ }^{33}{ }^{\mathrm{a}} \mathrm{Molecular}$ weight $>500 \mathrm{~g}$ mol ${ }^{-1}$.

and SI of 1.8 to 16 against yeasts of Candida genus. Complex $\mathbf{1}$ was highly selective for $C$. albicans (with SI 7.98), C. krusei (with SI 16), and C. glabrata (with SI 4). Thus, the new complexes we have synthesized have higher selectivity against fungal cells than mammalian cells. This result is in agreement with the chemoinformatics analysis, which shows that the complex has no irritant, reproductive or mutagenic effects (Table 4). In addition, the presence of metal in sodium hydrotris(2-mercaptothiazolyl)borate ligand was able to reduce liposolubility as presented by $\log \mathrm{P}$, which ranged from -0.99 to -1.33 (Table 4).

Chemo-informatic analysis showed that the number of hydrogen bond acceptor groups remained three with metal binding. The coordination compounds with $\mathrm{Cu}$ (II) and $\mathrm{Co}$ (II), as well as the ligand, suggested not to show irritant, reproductive or mutagenic effects by computational methods. In addition, we determined the compound compliance with the Lipinski's rule of five in order to predict oral absorption. ${ }^{32}$ Only the hydrotris(2-mercaptothiazolyl) borate ligand is in accordance with Lipinski's rule of five. Thus, $\mathrm{Cu}$ (II) and Co (II) complexes suggest a low oral bioavailability. The druglikeness of the complexes ranged from -2.86 to -4.56 . This is an indicator that combines topological descriptors (such as fragments of commercialized drugs with associated druglikeness scores) and physicochemical properties (such as cLogP and molecular weights) to quantitatively determine the therapeutic potential of a molecule. Many of the clinically available drugs have a druglikeness score in the range of 0.5 to 4 , while pharmacologically inert compounds generally have negative values. ${ }^{31}$ Thus, chemo-informatics analyses suggest that the metallic complexes employed in this study showed low pharmaceutical potential.

\section{CONCLUSIONS}

In conclusion, the ligand and its three metal complexes have been prepared and characterized. The antimicrobial activity assay revealed that the coordination process with copper and cobalt promoted an increase in the antimicrobial activity of the sodium hydrotris(2-mercaptothiazolyl)borate ligand. However, only complex 1 had an important pharmacological effect against the Candida species. In the evaluation of the cytotoxic effect in Vero cells, all the complexes presented reduced capacity of cellular injury, suggesting a low nephrotoxic potential. Complex 1 was 16 times more selective for $C$. krusei and almost 8 times more selective for C. albicans in relation to Vero cells. These results indicate that copper complexes are associated with increased antifungal activity and reduced toxicity. Due to the difficulty in developing drugs that are selective for fungal cells as a result of similarities to mammalian cells, copper coordination approaches are promising. Thus, complex 1 stands out as a potential prototype for the development of new antifungal agent.

\section{SUPPLEMENTARY MATERIAL}

Some images of the systems used in this work are available at http://quimicanova.sbq.org.br, in the form of a PDF file with free access.

\section{ACKNOWLEDGMENTS}

We would like to thank Universidade Federal de São João DelRei, Conselho Nacional de Desenvolvimento Científico e Tecnológico (CNPq), Coordenação de Aperfeiçoamento de Pessoal de Nível Superior (CAPES) and Fundação de Amparo à Pesquisa do Estado de Minas Gerais (FAPEMIG) by financial support, and Jéssica T. Andrade, William G. Lima are grateful to UFSJ and FAPEMIG for a fellowship.

\section{REFERENCES}

1. Garcia, L. M.; César, I. C. O.; Braga, C. A.; Souza, G. A. A. D.; Mota, E. C.; Rev. Epidemiol. Control Infect. 2013, 3, 45.

2. Ling, L. L.; Schneider, T.; Peoples, A. J.; Spoering, A. L.; Engels, I.; Conlon, B. P.; Mueller, A.; Schaberle, T. F.; Hughes, D. E.; Epstein, S.; Jones, M.; Lazarides, L.; Steadman, V. A.; Cohen, D. R.; Felix, C. R.; Fetterman, A. K.; Millett, W. P.; Nitti, A. G.; Zullo, A. M.; Chen, C.; Lewis, K.; Nature 2015, 517, 455.

3. Holmstrup, P.; Klausen, B.; Oral Dis. (2017), DOI: 10.1111/odi.12610.

4. Rai, M.; Ingle, A. P.; Pandit, R.; Paralikar, P.; Gupta, I.; Chaud, M. V.; Santos, C. A.; J. Pharm. (2017), DOI: 10.1016/j.ijpharm.2017.08.127.

5. Bus, L.; Coessens, G.; Boelens, J.; Claeys, G.; Decruyenare, J.; Depuydt, P.; Diagn. Microbiol. Infect. Dis. 2013, 77, 341.

6. Wang, J. H.; Harbarth, S.; Pittet, D.; Shou, M.; Zingg, W.; J. Hosp. Infect. 2017, 96, 1.

7. Xie, D. S.; Xiong, X.; Xiang, L.; Fu, X.; Yu, Y.; Liu, L.; Huang, S.; Wang, X.; Gan, X.; Xu, M.; Wang, H.; Xiang, H.; Xu, Y.; Nie, S.; J. Hosp. Infect. 2010, 76, 150 .

8. Alaghaz, A. N.; Bayoumi, H. A.; Ammar, Y. A.; Aldhlmani, S. A.; J. Mol. Struct. 2013, 1035, 383.

9. Zaslona, H.; Drozdzewski, P.; Slepokura, K.; J. Mol. Struct. 2015, 1100, 34.

10. Bakale, R. P.; Naik, G. N.; Machakanur, S. S.; Mangannavar, C. V.; Muchchandi, I. S.; Gudasi, K. B.; J. Mol. Struct. (2017), DOI: 10.1016/ j.molstruc.2017.10.035.

11. Soliman, S. M.; Elsilk, S. E.; J. Mol. Struct. (2017), DOI: 10.1016/j. molstruc.2017.07.072.

12. Yao, Z.; Jin, G.; Coord. Chem. Rev. 2013, 257, 2522.

13. Vinuelas-Zahinos, E.; Luna-Giles, F.; Torres-Garcia, P.; FernadezCalderon, M. C.; Eur. J. Med. Chem. 2011, 46, 150.

14. Makhaeva, G. F.; Boltneva, N. P.; Lushchekina, S. V.; Serebryakova, O. G.; Stupina, T. S.; Terentiev, A. A.; Serkov, I. V.; Proshin, A. N.; Bachurin, S. O.; Richardson, R. J.; Bioorg. Med. Chem. Lett. 2016, 24 , 1050. 
15. Netalkar, P. P.; Netalkar, S. P.; Revankar, V. K.; Polyhedron 2015, 100, 215.

16. Appelt, P.; Fagundes, F. D.; Facchin, G.; Kramer, G.; Back, D. F.; Cunha, M. A. A.; Sandrino, B.; Wohnrath, K.; Araujo, M. P.; Inorg. Chim. Acta 2015, 436, 152.

17. Rabie, U. M.; Abou-El-Wafa, M. H. M.; Nassar, H.; Spectrochim. Acta, Part A 2012, 86, 252.

18. Chen, H. C.; Wang, J. H.; Huang, J. Y.; Res. Chem. Intermed. 2014, 40, 2217

19. Soares, L. F.; Menezes, D. O.; Silva, R. M.; Dorigueto, A. C.; Ellena, J.; Mascarenhas, Y. P.; Castellanobet, E. E.; J. Braz. Chem. Soc. 2004, 15, 695.

20. Hill, A. F.; Owen, G. R.; White, A. J. P.; Willians, D. J.; Chem. Int. 1999, $38,2759$.

21. Hughes, B. C.; Lu, Z.; Jenkins, D. M.; Chem. Commun. 2014, 50, 5273.

22. Garner, M.; Lewinski, K.; Patter, A.; Reglinski, J.; Sieklucka, B.; Spicer, M. D.; Szaleniec, M.; Dalton Trans. 2003, 1, 1181.

23. Baba, H.; Nakano, M.; Polyhedron 2011, 30, 2182.

24. Reglinski, J.; Spicer, M. G.; Coord. Chem. Rev. 2015, 297, 181.

25. Clinical and Laboratory Standards Institute (CLSI); Reference Method for Broth Dilution Antifungal Susceptibility Testing of Yeasts, document M27-A3; Wayne, 2008.

26. Clinical and Laboratory Standards Institute (CLSI); Methods for Dilution Antimicrobial Susceptibility Test for Bacteria That Grow Aerobically, document M7-A6; Wayne, 2012.

27. Andrade, J. T.; Santos, F. R. S.; Lima, W. G.; Sousa, C. D. F.; Oliveira, L. S. F. M.; Ribeiro, R. I. M. A.; Gomes, A. J. P. S.; Araújo, M. G. F.; Villar, J. A. F. P.; Ferreira, J. M.; J. Antibiot. (Tokyo) (2018), DOI: 10.1038/s41429-018-0048-9.

28. Carvalho, R. S.; Carollo, C. A.; Magalhães, J. C.; Palumbo, J. M. C.; Boaretto, A. G.; Nunes, S. I. C.; Ferraz, A. C.; Lima, W. G.; Siqueira, J. M.; Ferreira, J. M. S.; S. Afr. J. Bot. 2018, 114, 181.

29. Souza, M. A.; Johann, S.; Lima, L. A. R. S.; Campos, F. F.; Mendes, I. C.; Beraldo, H.; Souza-Fagundes, E. M.; Cisalpino, O. S.; Rosa, C. A.; Alves, T. M. A.; Sá, N. P.; Zani, C. L.; Mem. Inst. Oswaldo Cruz 2013, 108,342 .
30. Nunes, B. C.; Martins, M. M.; Sérgio, R. C.; Morais, A. L.; Nascimento, E. A.; Luís, A. O.; Cunha, S. C.; Silva, C. V.; Teixeira, T. L.; Ambrósio, M. A. L. V.; Martins, C. H. G.; Aquino, F. J. T.; Ind. Crop. Prod. 2016, $92,277$.

31. Sander, T.; Freyss, J.; Von Korff, M.; Rufener, C.; J. Chem. Inf. Model. $\mathbf{2 0 1 5}, 55,460$.

32. Leeson, P.; Nature 2012, 481, 455.

33. Geary, W. J.; Coord. Chem. Rev. 1971, 7, 81

34. Doidge-Harrison, S. M. S. V.; Irvine, J. T. S.; Khan, A.; Spencer, G. M.; Wardell, J. L.; Aupers, J. A.; J. Organomet. Chem. 1996, 516, 199.

35. Little, L. H.; Ottewill, R. H.; Can. J. Chem. 1962, 40, 2110.

36. Joshi, R.; Ahmad, N.; Khan, A. S.; Hashmi, A. A.; J. Coord. Chem. 2010, 63, 906.

37. Muraoka, T. K.; Mauro, A. E.; Nogueira, V. M.; Haddad, O. S.; Eclet. Quim. 1997, 22, 75.

38. Yokoi, H.; Addison, A. W.; Inorg. Chem. 1977, 16, 1341.

39. Romanowski, S. M. M.; Tormena, F.; dos Santos, V. A.; Hermann, M. F.; Mangrich, A. S.; J. Braz. Chem. Soc. 2004, 15, 897.

40. Konstantinovic, S.; Radovanovic, B. C.; Cakic, Z.; Vasic, V.; J. Serb. Chem. Soc. 2003, 68, 641.

41. Lima, W. G.; Parreira, A. G.; Nascimento, L. A.; Leonel, C. A.; Andrade, J. T.; Palumbo, J. M.; Soares, A. C.; Granjeiro, P. A.; Ferreira, J. M. S.; J. Pharm. Negative Results (2017), DOI: 10.4103/jpnr.JPNR_11_17.

42. Dadar, M.; Tiwari, R.; Karthik, K.; Chakraborty, S.; Shahali, Y.; Dhama, K.; Microb. Pathog. (2018), DOI: 10.1016/j.micpath.2018.02.028.

43. Kadhum, A. A.; Mohamad, A. B.; Al-Amiery, A. A.; Takriff, M. S.; Molecules 2011, 16, 6969 .

44. Singh, U.; Malla, A. M.; Bhat, I. A.; Ahmad, A.; Bukhari, M. N.; Bhat, S.; Microb. Pathog. 2016, 93, 172.

45. Chudzik, B.; Czerne, L. G.; Miaskowski, A.; Gagoś, M.; Eur. J. Pharm. Sci. 2017, 97, 9.

46. Vaidya, M. Y.; McBain, A. J.; Butler, J. A.; Banks, C. E.; Whitehead, K. A.; Sci. Rep. 2017, 5911, 1.

47. Michael, E.; Kindgen-Milles, D.; Anaesthesist 2015, 64, 315.

48. Dorotíková, S.; Kozizková, J.; Malcek, M.; Jomová, K.; Herich, P.; Plevová, K.; Briestenská, K.; Chalupková, A.; Mistríková, J.; Milata, V.; Dvoranová, D.; Bucinsky, L.; J. Inorg. Biochem. 2015, 150, 1. 